\title{
Synthesis of Cyclic Peptides by the Peptide Claisen Rearrangement
}<smiles>C=CCOC(=O)CNC(=O)C(CC(C)C)NC(=O)C1CCCN1C(=O)C(N)C(C)C</smiles>

\section{Key words}

allylic esters

Claisen rearrangement

ring-closing metathesis

allylation

cyclic peptides

\section{Syníact $\dot{\mathrm{g}}$} (allylPdCl) $2(1 \mathrm{~mol} \%)$ $\mathrm{Ph}_{3} \mathrm{P}(4.5 \mathrm{~mol} \%)$ carbonate, THF t., $16 \mathrm{~h}$

$\mathrm{RuCl}_{2}\left(\mathrm{PCy}_{3}\right)_{2}(\mathrm{CHPh})$ $\mathrm{CH}_{2} \mathrm{Cl}_{2}$, reflux, $14 \mathrm{~h}$

Significance: Cyclic peptides are highly interesting motifs from the pharmaceutical point of view because of their significant biological activities. The authors demonstrated the application of the peptide Claisen rearrangement in syntheses of cyclic peptides.
Comment: Allylic peptides were synthesized by a tin chloride-mediated peptide Claisen rearrangement. Subsequent palladium-catalyzed $\mathrm{N}$-allylation and ring-closing metathesis afforded the corresponding cyclic peptides. 